\title{
Haemolytic uraemic syndromes in the British Isles 1985-8: association with Verocytotoxin producing Escherichia coli. Part 1: clinical and epidemiological
} aspects

\author{
D V Milford, C M Taylor, B Guttridge, S M Hall, B Rowe, H Kleanthous
}

\begin{abstract}
A prospective study of the clinical and epidemiological features of the haemolytic uraemic syndromes was conducted over a three year period in the British Isles. Two hundred and ninety eight children were reported. In two thirds of cases stool samples were analysed for the presence of Verocytotoxin producing Escherichia coli (VTEC) and neutralisable Verocytotoxin.
\end{abstract}

A total of $273(95 \%)$ patients had a prodrome of diarrhoea. In these a seasonal variation in the incidence of haemolytic uraemic syndrome was demonstrated, the 1-2 year age range was most often affected, and the peripheral blood neutrophil count correlated positively with an adverse outcome. Patients presenting without diarrhoea showed none of these associations and had a significantly greater morbidity and mortality.

Evidence for VTEC infection was found in $58(33 \%)$ of 178 diarrhoea associated cases whose stools were analysed, although VTEC were identified in five of eight $(62 \%)$ patients whose stools were collected within three days of the onset of diarrhoea. Most isolates produced VT2 either alone, or together with VT1. There was no evidence of VTEC infection in patients without prodromal diarrhoea.

The haemolytic uraemic syndromes comprise a heterogenous group of conditions in which microangiopathic haemolytic anaemia and acute renal impairment are concurrent. For practical purposes the syndromes can be divided into two

Department of

Nephrology,

The Children's Hospital, Birmingham (on behalf of the British Association for Paediatric

Nephrology)

D V Milford

C M Taylor

Communicable Diseases Surveillance Centre,

London

B Guttridge

$S$ M Hall

Division of

Enteric Pathogens, Central Public Health Laboratory, London

B Rowe

H Kleanthous

Correspondence to: Dr C M Taylor,

The Children's Hospital, Ladywood Middleway, Ladywood,

Birmingham B16 8ET.

Accepted 8 March 1990 ness of diarrhoea $(\mathrm{D}+)$ and the other withou (D-). ${ }^{12}$ The former is the commonest cause of acute renal failure of childhood in North America and Western Europe, and a good outcome can be expected in $>80 \%$ of contemporary cases. ${ }^{2}$ The rare $\mathrm{D}$ - form may be familial or relapsing, and carries a poor prognosis. An association between $\mathrm{D}+$ haemolytic uraemic syndrome and Verocytotoxin producing Escherichia coli (VTEC) was first demonstrated by Karmali et $a l^{3}$ and was subsequently reported from the United Kingdom and other countries. $^{4-7}$

Epidemiological surveillance of haemolytic uraemic syndrome in the British Isles began in 1983 as part of the voluntary clinical reporting scheme of the British Paediatric Association (BPA) and the Public Health Laboratory Communicable Disease Surveillance Centre (CDSC). ${ }^{8}$ From April 1985 members of the
British Association for Paediatric Nephrology (BAPN) collaborated with the Division of Enteric Pathogens of the Central Public Health Laboratory and the BPA-CDSC scheme. There were two principal purposes of the study: to describe the epidemiological and clinical features of an unselected, prospectively enrolled population of children with haemolytic uraemic syndrome, and to determine the role of VTEC in haemolytic uraemic syndrome in Britain. This paper focuses on clinical and epidemiological aspects, expanded bacteriological details being given in the accompanying paper. ${ }^{9}$

\section{Methods}

CASE ASCERTAINMENT

From 1 April 1985 to 31 March 1988 enrolment of patients under the care of BAPN members was initiated by the collection of a stool sample sent to the Division of Enteric Pathogens who subsequently notified CDSC. A clinical and epidemiological questionnaire was then sent to the referring clinician. Patients remaining solely under the care of general paediatricians were, until July 1986, reported to the study under the BPA-CDSC joint scheme. After that date they were ascertained via the British Paediatric Surveillance Unit (BPSU) active reporting scheme. ${ }^{10}$ Reports were followed up with the same questionnaire as that sent to BAPN members.

\section{QUESTIONNAIRE}

This requested basic epidemiological data, details of the prodrome, the clinical course of the illness, and laboratory findings.
SELECTION CRITERIA

Patients under 16 years of age with a clinical diagnosis of haemolytic uraemic syndrome supported by a review of the history and laboratory findings provided in the questionnaire were included in the study, the absolute requirement being microangiopathic anaemia and acute renal impairment. Thrombocytopenia, which may be evanescent in this disease, was considered to be strongly supportive of the diagnosis.

\section{SPECIMENS}

Faecal samples were obtained as soon as possible after presentation and forwarded to the Division of Enteric Pathogens for DNA probe tests for the presence of VTEC and examination for free neutralisable Verocytotoxin. ${ }^{511}$ These tests were in addition to any routine stool bacteriological analysis performed locally. 
OUTCOME

Outcome was determined by follow up questionnaires four months or more after diagnosis. Normotensive patients with body height/plasma creatinine concentration $(\mathrm{Ht} / \mathrm{pC})>2 \cdot 0 \mathrm{~cm} /$ $\mu \mathrm{mol} / \mathrm{l}$ and absent or 'trace' proteinuria on Albustix testing were considered to have a good outcome. The poor outcome group were those with treated hypertension, proteinuria (Albustix $\geqslant 1+)$, chronic renal failure $(\mathrm{Ht} / \mathrm{pC}<1 \cdot 5$, dialysis dependent or transplanted), and those who died. Patients with isolated $\mathrm{Ht} / \mathrm{pC}$ ratios between 1.5 and 2.0 were not included in the analysis as these values do not discriminate between normal and abnormal renal function. ${ }^{12}$

\section{DATA HANDLING}

Clinical, epidemiological, and laboratory data were entered into a database programme and statistical methods applied as appropriate (see text).

\section{Results}

(1) EPIDEMIOLOGY

Three hundred and three children were reported during the period 1 April 1985 to 31 March 1988. Ten children were reported from Northern Ireland and the Republic of Ireland (table 1), but data from this group were analysed separately as stool samples were unavailable for gene probe analysis in most cases. Five children were excluded as alternative diagnoses were suggested after biopsy or postmortem examination (three cases), or because of inadequate clinical data to substantiate the diagnosis (two cases).

Altogether $230(80 \%)$ of the 288 children were reported by BAPN members and the remainder by general paediatricians. Cases were reported each year from all regions of England, Scotland, and Wales. Annual reports increased during the study (table 2). There was a seasonal trend showing a summer peak in each year (fig 1). The age and sex distribution is shown in fig 2. The overall male:female ratio was $138: 150$ but in those aged 10-15 years there were seven boys and 21 girls. The incidence in England and Wales for the group aged $1-2$ years was $3 \cdot 3 / 10^{5}$ children/year, this being more than 10 times the incidence in those over 10 years old $\left(0 \cdot 27 / 10^{5}\right.$ children/year). Two hundred and eight two (98\%) children were white and six were Asians.
Table 2 Reported cases of haemolytic uraemic syndrome in children aged 0-15 years in mainland Britain 1985-8

\begin{tabular}{lcl}
\hline $\begin{array}{l}\text { Year } \\
\text { (April-March) }\end{array}$ & $\begin{array}{l}\text { No of } \\
\text { cases }\end{array}$ & $\begin{array}{l}\text { Cases } / 10^{5} \\
\text { children }\end{array}$ \\
\hline $1985-6$ & 81 & $0.65^{*}$ \\
$1986-7$ & 97 & $0.81 \dagger$ \\
$1987-8$ & 110 & $0.91 \neq$ \\
\hline
\end{tabular}

Office of Population and Census Surveys population estimates for: ${ }^{*} 1985,+1986, \ddagger 1987$.

The denominator populations for the ethnic groups are not precisely known, but it is estimated from the 1985 Labour Force Survey that $92 \%$ of children under 16 years of age were white. $^{13}$

\section{(2) CLINICAL AND LABORATORY DATA}

(a) D+ cases

Two hundred and seventy three $(95 \%)$ of the children had a prodrome of diarrhoea, which was described as bloody in 199. The mean (SD) duration of diarrhoea for those with bloody stools was 7 (5) days and for those with nonbloody diarrhoea 6 (4) days $p<0.025$ by Student's $t$ test. The mean time from onset of the prodrome to diagnosis was eight days (range 1 to 34 days), patients with a good outcome having a significantly longer time to diagnosis than those with a bad outcome; mean 8 (4) days compared with $6(2)$ days, $\mathrm{p}<0.01$ by Student's $t$ test). Two children had mild disease and were not admitted to hospital.

Forty children were reported to have had abdominal pain, of whom 11 underwent laparotomy. Seven were suspected of having appendicitis before the diagnosis of haemolytic uraemic syndrome was made and in all cases normal appendices were removed. Two children were operated on for intussusception. A further two children required bowel resections for complications of the associated colitis. Three other children had rectal prolapse.

Physical signs and clinical course-Pallor was reported in 251 (92\%) and jaundice in 96 (35\%) of cases. Fever occurred in $41(14 \%)$ and was not associated with the severity or duration of diarrhoea, the mean initial neutrophil count, highest plasma creatinine, duration of dialysis, or a poor outcome.

The hydration state as assessed on clinical

Table 1 Details of patients reported from Northern Ireland and the Republic of Ireland

\begin{tabular}{|c|c|c|c|c|c|c|}
\hline $\begin{array}{l}\text { Year of } \\
\text { study }\end{array}$ & $\begin{array}{l}\text { Age } \\
\text { (years) }\end{array}$ & Sex & $\begin{array}{l}\text { Type of } \\
\text { haemolytic uraemic } \\
\text { syndrome }\end{array}$ & Dialysis & VTEC & Outcome \\
\hline 1 & $8 \cdot 8$ & $M$ & D- & + & Not done & $\begin{array}{l}\text { End stage } \\
\text { renal failure }\end{array}$ \\
\hline 1 & $1 \cdot 1$ & $\mathbf{F}$ & D+ & + & - & $\begin{array}{l}\text { Chronic renal } \\
\text { failure }\end{array}$ \\
\hline $\begin{array}{l}2 \\
2 \\
2 \\
2 \\
3 \\
3 \\
3 \\
3\end{array}$ & $\begin{array}{l}0.2 \\
1.5 \\
0.9 \\
2.1 \\
0.2 \\
\text { Not known } \\
0.5 \\
0.8\end{array}$ & $\begin{array}{l}\mathbf{F} \\
\mathbf{F} \\
\mathbf{M} \\
\mathbf{M} \\
\mathbf{F} \\
\mathbf{F} \\
\mathbf{F} \\
\mathbf{F}\end{array}$ & $\begin{array}{l}\text { D+ } \\
\text { D+ } \\
\text { D+ } \\
\text { D+ } \\
\text { D+ } \\
\text { D+ } \\
\text { D+ } \\
\text { D+ }\end{array}$ & $\begin{array}{l}+ \\
+ \\
+ \\
+ \\
+ \\
+ \\
+ \\
+\end{array}$ & $\begin{array}{l}\text { Not done } \\
+ \\
\text { Not done } \\
- \\
\text { Not done } \\
\text { Not done } \\
\text { Not done } \\
\text { Not done }\end{array}$ & $\begin{array}{l}\text { Died } \\
\text { Recovered } \\
\text { Not known } \\
\text { Recovered } \\
\text { Recovered } \\
\text { Recovered } \\
\text { Hypertensive } \\
\text { Recovered }\end{array}$ \\
\hline
\end{tabular}

${ }^{*}$ 1: April 1985-March 1986; 2: April 1986-March 1987, 3: April 1987-March 1988. 


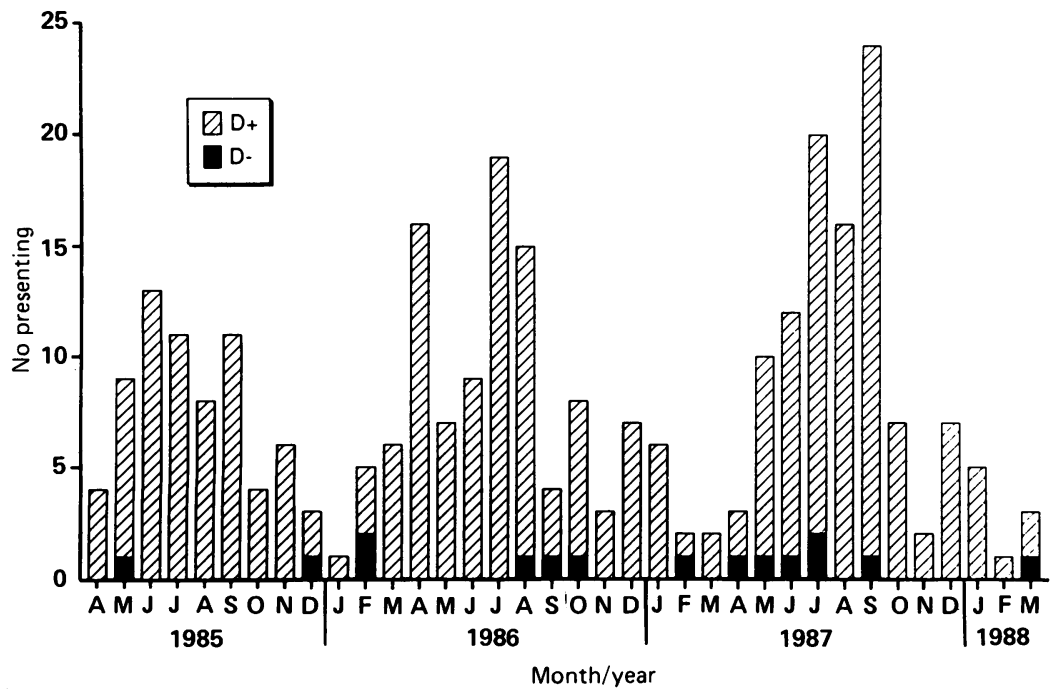

Figure 1 Distribution of cases of haemolytic uraemic syndrome by month showing seasonality confined to $D+$ patients.
Hypertension developed in 86 (32\%) of whom 29 had concurrent seizures or neurological symptoms or signs. In 11 the central nervous system disturbances occurred within two days of the onset of hypertension. No temporal association was found between hypertension and intracranial haemorrhage, which was reported in 18 patients.

Seizures occurred in $51(19 \%)$ patients: in 34 $(67 \%)$ within 24 hours of the lowest recorded plasma sodium concentration and in $36(71 \%)$ within three days of admission. Hyponatraemia (plasma sodium concentration $<130 \mathrm{mmol} / \mathrm{l}$ ) was noted in 203 children during the acute illness. The lowest recorded plasma sodium occurred on the day of admission in 67 , but a further $77(38 \%)$ reached the nadir of hyponatraemia four or more days from admission. In 26 children the lowest sodium occurred while on dialysis, and of these four developed seizures and one died. The degree of hyponatraemia for children with seizures was greater than for those without (mean sodium $123 \mathrm{mmol} / \mathrm{l}$ compared with $128 \mathrm{mmol} / \mathrm{l} ; \mathrm{p}<0.001$ by Student's $t$ test), and while 111 of $220(50 \%)$ children without seizures were hyponatraemic at some stage, it was present in $43(84 \%)$ of those with seizures.

Abnormalities of red cell morphology were reported as fragmented cells, burr cells, spherocytes, or polychromasia. Fragmented red cells were the commonest reported abnormality of erythrocyte morphology and were seen in 262 (96\%) children; 254 (93\%) of the patients had two or more of the above abnormalities and 194 (71\%) had three or more abnormalities. Subnormal platelet counts returned to normal within one week in 132 of $255(52 \%)$ children in whom this information was provided, although $22(9 \%)$ had not returned to normal by two weeks from admission. No significant difference in the lowest platelet count was found either between patients with or without oliguria, or between those requiring or not requiring dialysis. Neither was there a significant difference in the time taken for platelets to return to normal $\left(>130 \times 10^{9} / 1\right)$ between out-

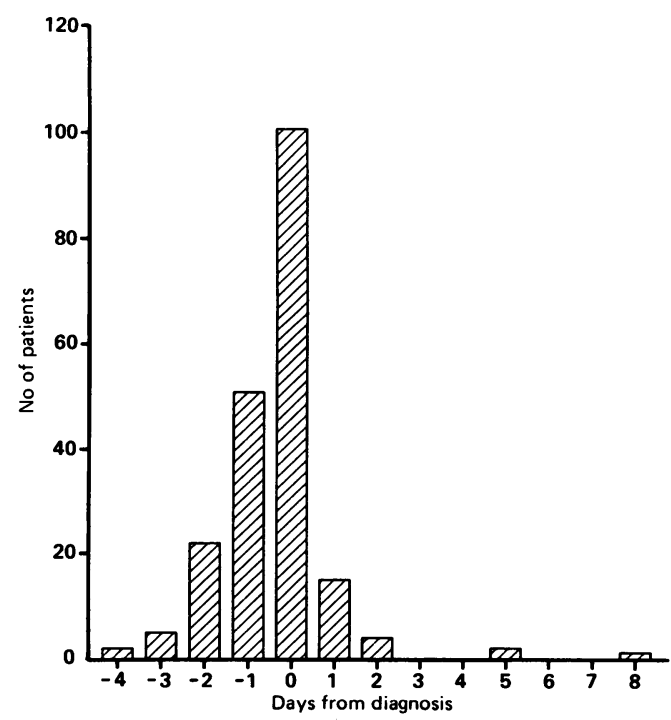

Figure 3 The onset of oliguria related to the time of diagnosis of haemolytic uraemic syndrome. grounds at the time of admission was recorded in 272 cases: $139(50 \%)$ were reported to be normally hydrated, $60(22 \%)$ overloaded, and 68 $(25 \%)$ dehydrated. Five children $(2 \%)$ were reported to be shocked on admission, and of these one died.

Oligoanuria was reported in 209 of 269 children; in 102 it had developed on or before the day of admission, in a further 46 by 48 hours, and a further 60 within one week from admission. Only $130(60 \%)$ children were diagnosed as having haemolytic uraemic syndrome on the day of onset of oligoanuria and in some the diagnosis was not made until two or more days from the recognition of renal failure (fig 3). Fourteen children were reported to have had high output renal failure during the course of their illness. Dialysis was required in 157 (58\%) children for a mean duration of $\mathbf{9 . 4}$ days (range 1-26 days) though the total duration of dialysis was not always recorded and may have exceeded the quoted range. 
come groups. Seventy six patients had a platelet count $>130 \times 10^{9} / 1$ on admission of whom 20 never had platelet counts $<130 \times 10^{9} / 1$ reported during their illness.

Four children developed a cardiomyopathy within 10 days from admission, ${ }^{14}$ and a further four children developed diabetes mellitus between nine and 14 days from admission. ${ }^{15} 16$

\section{(b) D-cases}

Ten boys and five girls did not have diarrhoea but 13 of this group had prodromal features consisting of vomiting or respiratory symptoms. There was a single instance of diarrhoea and vomiting in other family members but the index case had vomiting and respiratory symptoms only. One boy belonged to a previously reported family with hereditary haemolytic uraemic syndrome. ${ }^{17}$ One child was Asian, 14 were white, and their mean age was $5 \cdot 7$ years.

Pallor was noted on admission in 14 children and jaundice in six. None was feverish. Four children were assessed on admission as being fluid overloaded and two dehydrated. Oligoanuria developed in nine cases and one developed high output renal failure; seven children required peritoneal dialysis and one haemodialysis. Plasma exchanges were used in four cases. Hypertension developed in seven children and persisted in six. Disturbances of the central nervous system or seizures occurred in four cases, three of whom were hyponatraemic; two children had central nervous system haemorrhages.

Burr cells and fragmented cells were the commonest reported abnormality of red cell morphology, and thrombocytopenia was present in 14 cases. Stools were obtained from seven children and none were shown to have VTEC or neutralisable free Verocytotoxin. As the onset of illness in these patients is ill defined it is impossible to time stool collection accurately; however, stool samples were obtained between eight and 21 days from diagnosis.

\section{(3) MICROBIOLOGY}

Stool samples were obtained from a total of 196 children, and coliforms were cultured from 178 D+ cases. Fifty three VTEC were identified in 52 samples and gene probe analysis showed that three were Verocytotoxin 1 (VT1) producing organisms, 44 produced VT2 only, and six produced VT1 and VT2. Significant titres of neutralisable free Verocytotoxin were found in six cases in the absence of VTEC, implicating VTEC in a total of $58(33 \%)$ of $\mathrm{D}+$ cases. The excretion of VTEC after infection was brief and the isolation of VTEC depended on the timing of stool collection (fig 4). In order to compare the clinical findings between VTEC positive and VTEC negative patients we analysed subgroups. No significant differences were found in clinical variables between 27 VTEC positive and 28 VTEC negative $\mathrm{D}+$ patients whose stools were analysed within seven days of onset of diarrhoea (table 3). VTEC were isolated concurrently with Campylobacter jejeuni from one patient, and enteropathic $E$ coli (EPEC) from

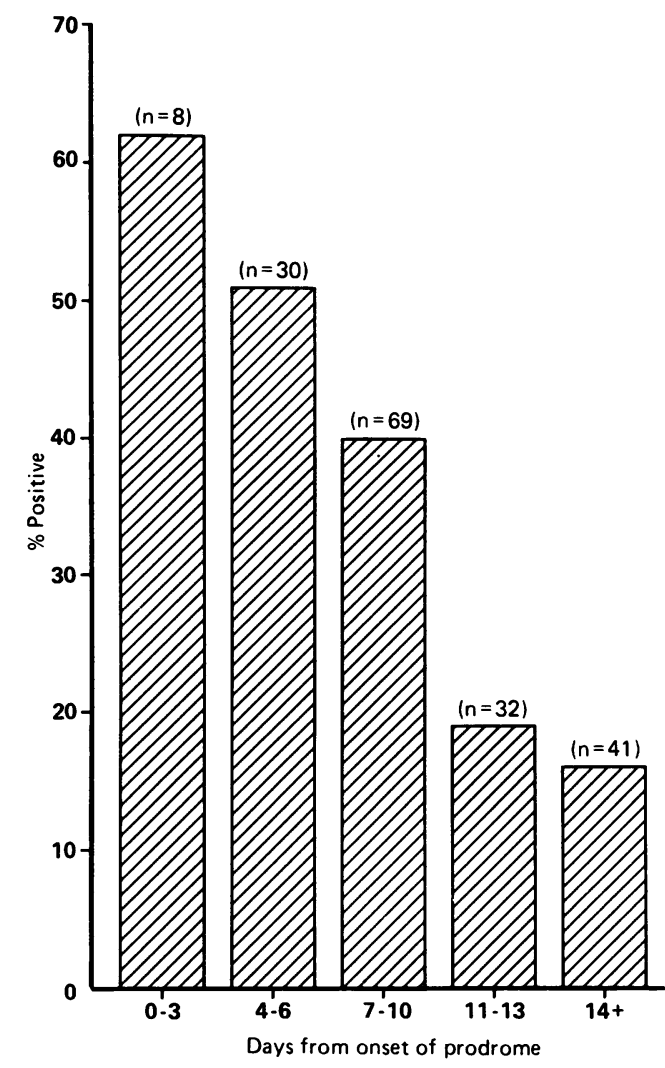

Figure 4 Isolation of VTEC and time from the onset of prodrome.

another. Other faecal organisms isolated by local laboratories included five EPEC, two campylobacter, two salmonella, two Clostridium difficile, and single isolates of Entamoeba hystolytica and Candida albicans.

Sixteen children had travelled overseas in the month before the onset of the illness: 14 having visited Europe and two the Indian subcontinent. Organisms were isolated from five cases: $\operatorname{EPEC}(n=2)$, and single isolates of VTEC, a salmonella, and Shigella dysenteriae type 1 .

\section{(4) outcome}

Follow up data were obtained for 272 of the 288 patients but were insufficient to allocate an outcome group in all cases. Two hundred and fifty two $\mathrm{D}+$ and $14 \mathrm{D}$ - children were followed up for a minimum of four months (mean 13 months, range 4 to 40 months) and table 4 summarises their outcome and illustrates the difference between $\mathrm{D}+$ and $\mathrm{D}-$ groups.

Table 3 Patients with stool samples obtained within the first week of diarrhoea: clinical features and outcome at $\geqslant 4$ months

\begin{tabular}{lrrl}
\hline & VTEC + & VTEC- & $p$ Value \\
\hline Total No & 27 & 28 & \\
Bloody diarrhoea & 19 & 20 & NS \\
Non-bloody diarrhoea & 8 & 8 & NS \\
Mean (SD) days of diarrhoea & $5(2)$ & $6(3)$ & NS \\
Acute hypertension & 9 & 13 & NS \\
Dialysed & 17 & 16 & NS \\
Died & 6 & 1 & $<0.05$ \\
Outcome data available & 16 & 17 & \\
$\quad$ (survivors) & 12 & 13 & NS \\
Good outcome & 4 & 4 & NS \\
Sequelae & & & \\
\hline
\end{tabular}


Table 4 Incidence and outcome of diarrhoea associated $(D+)$ and non-diarrhoeal $(D-)$ cases $(n=288)$

\begin{tabular}{|c|c|c|}
\hline & $D+$ & $D-$ \\
\hline $\begin{array}{l}\text { No }(\%) \text { reported } \\
\text { No }(\%) \text { dialysed }\end{array}$ & $\begin{array}{l}273(95) \\
157(58)\end{array}$ & $\begin{aligned} 15 & (5) \\
8 & (53)\end{aligned}$ \\
\hline $\begin{array}{l}\text { Outcome at } \geqslant 4 \text { months } \mathrm{f} \\
\text { No followed up } \\
\text { Lone hypertension } \\
\mathrm{Ht} / \mathrm{pC}<1 \cdot 5 \\
\text { End stage renal failure } \\
\text { Died }\end{array}$ & $\left.\begin{array}{l}m \text { diagnosis: } \\
252 \\
2 \\
17 \\
0 \\
14\end{array}\right\} 13 \%$ & $\left.\begin{array}{rl}14 & \\
2 \\
2 \\
4 \\
3\end{array}\right\} 79 \%$ \\
\hline
\end{tabular}

Table 5 Initial neutrophil count and outcome at $\geqslant 4$ months from diagnosis

\begin{tabular}{lll}
\hline Outcome & $\begin{array}{l}\text { Neutrophil coumt } \\
<20 \times 10^{*}: 1\end{array}$ & $\begin{array}{l}\text { Niutrophil count } \\
\geqslant 20 \times 10^{*} l\end{array}$ \\
\hline Good & 135 & 21 \\
Poor & 20 & 13 \\
\hline $\mathrm{p}<0.005$ by $\chi^{2}$. & &
\end{tabular}

In $\mathrm{D}+$ patients those with a poor outcome were more likely to have been dialysed than those with a good outcome $\left(\mathrm{p}<0.001\right.$ by $\chi^{2}$ test $)$, and $12(35 \%)$ of children with a poor outcome were dialysed for more than 14 days compared with $20 \%$ of those with a good outcome. There was no association between outcome and the time from onset of diarrhoea to the start of dialysis. No relapses of haemolytic uraemic syndrome were reported in $\mathrm{D}+$ cases. Fourteen children $(5 \%)$ died in the acute illness. All were less than 5 years of age, experienced seizures or central nervous system disturbances, and required dialysis. Death was ascribed to central nervous system causes in 10 .

Of the 86 children with hypertension 84 were followed up for four months or more and three remained hypertensive. One child subsequently developed hypertension having been normotensive in the acute phase.

The initial neutrophil count was closely correlated with outcome (table 5). Moreover, there was an association between neutrophilia and both oligoanuria and the need for dialysis $(p<0.005$ and $p=0.05$ respectively by MannWhitney).

\section{Discussion}

In this British study the annual reported incidence, mean age of cases, and the summerautumn seasonality are comparable with reports from four recent population based studies from the United States. ${ }^{48-20}$ The apparent increase in the incidence of haemolytic uraemic syndrome from 1985 to 1988 must be interpreted with caution as case ascertainment was enhanced in 1986 by the BPSU reporting scheme, although the increase continued in 1987, a year of unchanging methodology. Moreover, since the completion of the study the number of cases reported annually to the BPSU have continued to rise (S M Hall, personal communication).

There was an excess of girls among the 273 with $\mathrm{D}+$ haemolytic uraemic syndrome, the inequality being most noticeable in children over the age of 10 years, an unexplained find- ing. This inequality has been previously reported both in the United Kingdom ${ }^{8}$ and the United States, ${ }^{4}$ 18-20 which contrasts with the predominance of males among $\mathrm{D}-$ cases. The incidence of haemolytic uraemic syndrome was higher than expected in white children, a finding noted in other populations. ${ }^{21} 22$

Dolislager and Tune suggested that $\mathrm{D}+$ and D- cases should be considered separately as the incidence, morbidity, and mortality for the two forms of haemolytic uraemic syndrome are very different. ${ }^{23}$ This is supported by our study (table 4), which shows that renal impairment at four months or more from diagnosis occurred in $8 \%$ of $\mathrm{D}+$ and $73 \%$ of $\mathrm{D}$ - survivors $(10.8 \%$ of all survivors). However, late decline in renal function can occur. Some patients with the Dform experience relapses of the disease, and survivors of $\mathrm{D}+$ haemolytic uraemic syndrome who have lost a large proportion of their nephrons in the acute phase may eventually develop progressive segmental sclerosis in the same way as other patients with reduced renal mass. For these reasons patients should be monitored for a prolonged period after apparent recovery.

Children who died were all aged less than 5 years, but the small numbers precluded analysis to determine a specific effect of age or sex on outcome. Two thirds of those who died had central nervous system causes for their deaths. Long term central nervous system sequelae were uncommon, however, only one of the 61 children with central nervous system disturbances in the acute phase had neurological sequelae. This is in contrast to the experience from the west Midlands outbreak, in which four out of 35 survivors had residual neurological impairment. ${ }^{2+}$ The importance of hyponatraemia and its association with central nervous system disturbances has been previously reported, ${ }^{2+-26}$ and is re-emphasised in this report. The problem appears to be that in many cases there was a time delay between the onset of oligoanuria and recognition of the diagnosis of haemolytic uraemic syndrome (fig 3), during which time water administration may have been inappropriate.

Our finding that up to $62 \%$ of stools obtained early in the course of the disease are positive for Verocytotoxin or VTEC confirms the importance of this organism in the aetiology of the disease. As the excretion of VTEC is brief ${ }^{27}$ and diarrhoea has often waned by the time patients are admitted with haemolytic uraemic syndrome, this study may underestimate the true association with VTEC. It is therefore difficult to be certain which patients, if any, were truly VTEC negative and to ascribe specific clinical features to VTEC infection. We found a greater number of deaths in patients positive for VTEC whose stools were analysed within the first week of diarrhoea. However, there were no other differences in the clinical features of patients positive or negative for VTEC (table 3).

While VTEC belonging to the serotype 0157:H7 are now frequently associated with haemorrhagic colitis and haemolytic uraemic syndrome, reviews of $E$ coli isolates held in North American and United Kingdom refer- 
ence centres rarely identified this pathogen before the early $1980 \mathrm{~s}^{27} 28$ Similarly, with the recent emergence of $S$ dysenteriae type 1 as the predominant pathogen in some tropical regions the incidence of haemolytic uraemic syndrome has increased. ${ }^{29} S$ dysenteriae type 1 elaborates a toxin that is functionally and structurally identical to $\mathrm{VT}^{30}$ and similar to VT2. Our finding that $94 \%$ of VTEC were VT2 producing organisms is in keeping with reports from other studies, 5731 but the implications of this are unclear. Butler et al have shown that in shigellosis a high white cell count is a risk factor for the development of haemolytic uraemic syndrome, ${ }^{32}$ and Walters et al found a positive association between neutrophilia and poor outcome in D+ haemolytic uraemic syndrome, ${ }^{2}$ an observation confirmed in this analysis. Parallels therefore appear to exist between haemolytic uraemic syndrome associated with $S$ dysenteriae type 1 infection and VTEC associated disease seen in temperate zones. ${ }^{29} 3033$

This study of British children confirms and extends the previously reported association between VTEC and D+ haemolytic uraemic syndrome, ${ }^{34}$ and illustrates the importance of VT2 producing organisms. The distinction between $\mathrm{D}+$ and $\mathrm{D}-$ patients is validated not only by the pronounced differences in the incidence and outcome of the two forms of haemolytic uraemic syndrome but also the association of VTEC in the former group and absence of VTEC in the latter. Moreover, the correlation between initial neutrophil count and outcome is confined to the $\mathrm{D}+$ patients. The haemolytic uraemic syndromes cause the death of five to six children per year in the United Kingdom. The impact of haemolytic uraemic syndrome on the number of children or young adults entering end stage renal failure programmes has yet to be established as a late decline of renal function may occur in some survivors. Therefore it is important that the outcome of this cohort of children should be the subject of future analysis.

The authors thank paediatric colleagues and members of the British Association for Paediatric Nephrology for reporting their patients. The study was generously supported by the National Kidney Research Fund (Grant No 86/1/15) and the Rena Research Fund of the Children's Hospital, Birmingham.

1 Levin M, Barratt TM. Haemolytic uraemic syndrome. Arch Dis Child 1984;59:397-400.

2 Walters MDS, Matthei IU, Kay R, Dillon MJ, Barratt TM. The polymorphonuclear leucocyte count in childhood haemolytic uraemic syndrome. Pediatric Nephrology 1989; 3:130-4.

3 Karmali MA, Steele BT, Petric M, Lim C. Sporadic cases of hemolytic uremic syndrome associated with faecal cytotoxin and cytotoxin-producing Escherichia coli in stools. Lancet 1983; : 619 .

4 Neill MA, Tarr PI, Clausen CR, Christie DL, Hickman RO.Escherichia coli 0157:H7 as the predominant pathogen associated with the hemolytic uremic syndrome: a prosassociated with the hemolytic uremic syndrome: a pros-
pective study in the Pacific Northwest. Pediatrics 1987;80: pective
$37-40$.

5 Scotland SM, Rowe B, Smith H, Willshaw G, Gross R. Verocytotoxin-producing strains of Escherichia coli from children with haemolytic uraemic syndrome and their
detection by specific DNA probes. $\mathcal{F}$ Med Microbiol 1988; 25:237-43.
6 Novillo AA, Voyer LE, Cravioto R, et al. Haemolytic uraemic syndrome associated with faecal cytotoxin and verotoxin neutralizing antibodies. Pediatric Nephrology 1988;2:288-90.

7 Bitzan M, Karch H, Klemt M, Buren J, Altrogge H. Relevance of verotoxin mediated hemolytic uremic syndrome in Germany. Nieren-und Hochdruck Krankheiten 1988;17: in $\mathrm{G}$

8 British Paediatric Association-Communicable Disease Surveillance Centre. Surveillance of haemolytic uraemic syndrome 1983-4. Br Med F 1986;292:115-7.

9 Kleanthous H, Smith HR, Scotland SM, et al. Haemolytic uraemic syndromes in the British Isles 1985-8: association with Verocytotoxin producing Escherichia coli. Part 2: microbiological aspects. Arch Dis Child 1990;65:722-7.

10 Hall SM, Glickman M. The British Paediatric Surveillance Unit. Arch Dis Child 1988;63:344-6.

11 Willshaw GA, Smith HR, Scotland SM, Field AM, Rowe B. Heterogeneity of Escherichia coli phages encoding Vero cytotoxins: comparison of cloned sequences determining VT1 and VT2 and development of specific gene probes. f Gen Microbiol 1987;133:1309-17.

12 Haycock GB. Creatinine, boidy size and renal function. Pediatric Nephrology 1989;3:22-4.

13 Office of Population Censuses and Surveys. Labour Force Survey 1985: ethnic group and country of birth. London: Office of Population Censuses and Surveys, 1986. (OPCS monitor; LFS 86/2.)

14 Poulton J, Taylor CM, De Giovanni JV. Dilated cardiomyopathy associated with haemolytic uraemic syndrome. Br Heart $\mathcal{F}$ 1987;57:181-3.

15 Andreoli SP, Bergstein JM. Development of insulindependant diabetes mellitus during the hemolytic-uremic syndrome. F Pediatr 1982;100:541-5

16 Burns JC, Berman ER, Fagre JL, Shikes RH, Lum GM. Pancreatic islet cell necrosis: association with hemolytic uremic syndrome. $f$ Pediatr 1982;100:582-4.

17 Farr MJ, Roberts S, Morley AR, Dewar PJ, Roberts DF, Uldall PR. The haemolytic uraemic syndrome - a family study. $O$ F Med 1975;174:161-88.

study. $Q \mathcal{F}$ Med 1975;174:161-88.
18 Rogers MF, Rutherford GW, Alexander SR. A populationbased study of hemolytic-uremic syndrome in Oregon, 1979-1982. Am f Epidemiol 1986;123:137-42.

19 Kinney JS, Gross TP, Porter GC, Rogers MF, Schonberger LB, Hurwitz ES. Hemolytic uremic syndrome: a population-based study in Washington, DC and Baltimore, Maryland. Am $\mathcal{F}$ Public Health 1988;78:64-5.

20 Tarr PI, Hickman RO. Hemolytic uremic syndrome epidemiology: A population-based study in King County, Washington, 1971 to 1980 . Pediatrics 1987;80:41-5.

21 Kibel M, Barnard PJ. The haemolytic uraemic syndrome-a survey in Southern Africa. S Afr Med $\mathcal{F} 1968 ; 42: 692-8$.
savies $P$. The haemolytic uraemic syndrome. East Afr Med f 1968;48:136-9.

23 Dolislager D, Tune B. The hemolytic-uremic syndrome. Spectrum of severity and significance of prodrome. $\mathrm{Am}$ Spectrum of severity and sis

24 Taylor CM, White RHR, Winterborn MH, Rowe B. Haemolytic-uraemic syndrome: clinical experience of an outbreak in the West Midlands. Br Med F 1986;292: 1513-6.

25 Bale JF, Brasher C, Siegler RL. CNS manifestations of the hemolytic-uremic syndrome. Am $\mathcal{F}$ Dis Child 1980;134: 869-72.

26 Milford DV, Taylor CM. Hyponatraemia and haemolytic uraemic syndrome. Lancet 1989;i:439.

27 Wells JG, Davis BR, Wachsmuth IK, et al. Laboratory investigation of hemorrhagic colitis outbreaks associated with a rare Escherichia coli serotype. 7 Clin Microbiol 1983;18: 512-20.

28 Day NP, Scotland SM, Cheasty T, Rowe B. Escherichia coli 0157:H7 associated with human infections in the United Kingdom. Lancet 1983;i:825.

29 Raghupathy P, Date A, Shastry JC, Sudarsanam A, Jadhav $M$. Haemolytic-uraemic syndrome complicating shigella dysentery in south Indian children. $\mathrm{Br}$ Med $\mathcal{f}$ 1978;i: dysentery

30 O'Brien AD, La Veck G. Purification and characterization of a Shigella dysenteriae 1-like toxin produced by Escherichia coli. Infect Immun 1983;40:675-83.

31 Tarr P, Neill M, Clausen C, Newland J, Neill R, Moseley S. Genotypic variation in pathogenic Escherichia coli 0157:H7 isolated from patients in Washington, 1984-1987. F Infect Dis 1989;159:344-7.

32 Butler T, Islam MR, Azad MA, Jones PK. Risk factors for development of hemolytic uremic syndrome during shigellosis. I Pediatr 1987;110:894-7.

33 Rahaman MM, Alam AK, Islam MR. Shiga bacillus dysentery associated with marked leukocytosis and erythrocyte fragmentation. Fohn Hopkins Medical foumal 1975;136: 65-70.

34 Karmali MA, Petric M, Lim C, Fleming PC, Arbus GS, Lior $H$. The association between idiopathic hemolytic uremic syndrome and infection by verocytotoxin-producing Escherichia coli. F Infect Dis 1985;151:775-81. 